\title{
Analysis on the International Competitiveness of Beijing's Cultural Creative Industries
}

\author{
Kexin Cao, Jishun Niu \\ Business School, Beijing Institute of Fashion Technology, Beijing, China \\ Email:sxynjs@bift.edu.cn
}

How to cite this paper: Cao, K.X. and Niu, J.S. (2017) Analysis on the International Competitiveness of Beijing's Cultural Creative Industries. American Journal of Industrial and Business Management, 7, 143-159. https://doi.org/10.4236/ajibm.2017.73011

Received: March 26, 2016

Accepted: March 12, 2017

Published: March 15, 2017

Copyright $\odot 2017$ by authors and Scientific Research Publishing Inc. This work is licensed under the Creative Commons Attribution International License (CC BY 4.0).

http://creativecommons.org/licenses/by/4.0/ (c) (i) Open Access

\begin{abstract}
This paper analyzes the competitiveness of Beijing's cultural creative industries, investigates the overall competitiveness of Beijing's cultural creative industries in the international market share, and reveals the comparative advantage and industrial competitiveness of Beijing's cultural creative industries in cultural creative products and cultural creative services. This study comprehensively evaluates the competitiveness of Beijing's cultural creative industries.
\end{abstract}

\section{Keywords}

Cultural Creative Industries, Export Trade, Competitiveness

\section{Introduction}

For a long time, China's economic development mainly depended on the economic development of general processing industries and on extending the path of economic development by increasing the number of processing industries. China's economic development relied on expanding the scale of investment and excessively increasing material input. China accelerated the pace of development by converting the existing extensive economy and industrial structure into a resource-saving and environment-friendly industrial structure at the beginning of the 21 st century.

Beijing is the center of China's culture and is dedicated to the development of cultural creative industries. This development is an effective measure to fully implement the transformation and upgrading of industrial structure and to stimulate the economic growth mode transformation. It is also the only path Beijing must take to enhance its independent innovation ability and to construct an innovative city. The optimization of the development of cultural creative industries can meet the growing material and cultural needs of the residents. The world will know more about Beijing and be acquainted with China by raising the export 
trade scale of cultural creative industries.

\section{Current Situation of Beijing's Cultural Creative Industries}

Beijing is a famous historical city in the world, and it is attracting global attention because of its history of thousands of years, cultural ethos, and rapidly developing economy, science, and technology levels. Beijing's advantages are also a foundation for the development of cultural creative industries. Beijing has recently considered cultural development to be important in adjusting its industrial structure and transforming its economic development mode. The cultural creative industry, with its vigorous promotion and rapid development in the 12th Five-Year plan, has become an important pillar and a new economic growing point of Beijing's economy.

\subsection{Promotion of Economic Growth}

The added value of Beijing's cultural creative industries shown in Figure 1 maintained a momentum of rapid growth from 2005 to 2014. The added value of Beijing's cultural creative industries in 2014 was 279.43 billion yuan, and it accounted for $13.1 \%$ of Beijing's gross domestic (GDP). By the end of 2014, about 0.17 million cultural creative enterprises were established in Beijing, which is $15 \%$ higher than that in the previous year, with a registered capital of 433.85 billion yuan, which is $39.4 \%$ higher than that in the same period in the previous year. Corporate units above the designated size brought in 1102.9 billion yuan in sales, which is $9.5 \%$ greater than that in the last year. The number of employees in cultural creative industries was 1.097 million, which is $2.2 \%$ greater than that in 2013 . Beijing's cultural creative industries, under the transformation of economic development and the adjustment of economic growth speed, have an obvious driving role in economic growth, which shows a strong anti-risk.

\subsection{Rapid Development of Related Industries}

The science and technology industry has increased significantly in cultural creative

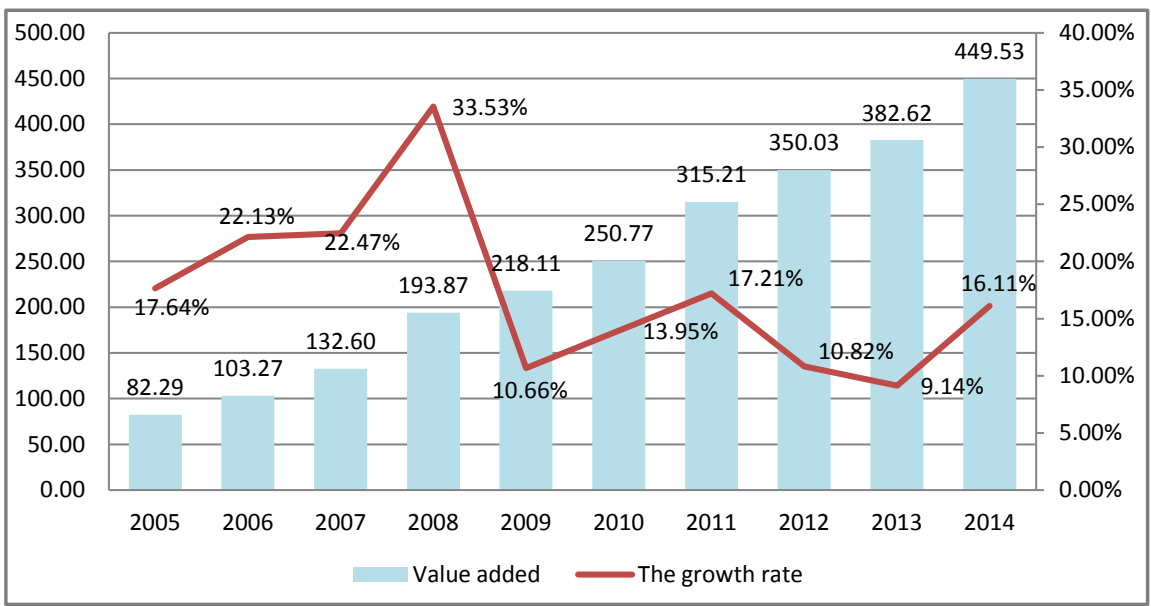

Figure 1. Added value and growth rate of Beijing's cultural creative industries unit: billion USD. Data sources: Report on the market prospective of China's cultural creative industries and financial strategy. 
industry sectors (i.e., movie and TV industry). In 2014, the revenues of the above-scale cultural and arts industry and the broadcasting movie and TV industry were $8.5 \%$ and $11.6 \%$ over the same period in the previous year and $1.4 \%$ and $2.4 \%$ higher in 2013 , respectively. The added value of the software service and information technology service industry, which includes 17 subcategories (14 of which belong to cultural creative industries), increased by $11.7 \%$ and was $4.4 \%$ higher than the GDP growth in Beijing. The added value of this industry contributes to the added value accounting by more than $13 \%$ [1].

With the increasing demand of Beijing's residents for material and culture, purchasing power has continuously stimulated and driven the development of cultural creative industries in recent years. Beijing residents' per-capita spending on cultural creative products and services was 3256 yuan in 2014, which is higher by $8.6 \%$ than that in 2013. Cinema income in the movie and TV industry was 2.3 billion yuan, which is higher by $25 \%$ than that in 2013 . The box office per capita in Beijing was the first among first-tier cities. However, Beijing residents' consumption in the cultural creative products and services has more room for improvement than that of developed countries. The statistical data show that the driving effect of the cultural creative industry imperceptibly influences the transformation of Beijing's industries. Beijing cut down non-capital functions in accordance with the development strategy of Four Centers in 2013 to establish a high, excellent, and cutting-edge intensive industrial structure, transformed 392 manufacturing enterprises and 36 trading markets, and reduced the growth rate of the labor-intensive and wholesale and retail industries. Beijing is currently focusing on the development of its cultural creative industries to fill the gap after the adjustment of the industrial structure and the transformation of the manufacturing enterprise. The supporting role of Beijing's cultural creative industries in the economic development is apparent and relies on a series of support policies for the cultural creative industries in China.

\subsection{Reduction of Key Export Enterprises}

About 49 key cultural export enterprises were identified in Beijing in 2007 to 2008. This number accounted for $34.51 \%$ of the country's enterprises. Around 56 Beijing's enterprises were included in List of National Key Enterprises in Cultural Export in 2009 to 2010, and they accounted for $26.54 \%$ of the whole country's enterprises. Compared with the previous two years, the net increase was 7 , and the actual number of new enterprises was 13 , which mainly included some private enterprises in press and publication and science and technology. About 71 of Beijing's enterprises were included in List of National Key Enterprises in Cultural Export in 2011 to 2012, and they accounted for 14.52\% of the whole country. The proportion to the country decreased compared with that of the previous year. However, the net increasing value was 15, and the actual number of new enterprises was 35 , which remained mainly private. Moreover, the support industries of Beijing's cultural creative export are mainly news and broadcasting and movie and TV industries. About 60 of Beijing's enterprises were included in the 2013 to 2014 List of National Key Enterprises in Cultural Export, and they ac- 
counted for $16.39 \%$ of the whole country's enterprises. The number of Beijing's cultural creative key export enterprises was lower than that the previous year. The actual number of new enterprises was 12. CCTV Animation Co., Ltd. is exclusively state-owned, and the remaining enterprises are privately owned. The actual number of decreasing enterprises was 23 , which were mainly private companies that focused on science and technology, movies, and TV [2].

\section{Current Situation of Beijing's Cultural Creative Industry Export Trade}

\subsection{The Continuously Expanded Scale}

This paper compares the general situation of China's cultural creative industry export trade from 2003 to 2012 to better analyze the present situation of Beijing's cultural creative industry export trade. Table 1 shows that China's cultural creative industry export trade scale expanded from 2003 to 2012, with the export volume of cultural creative products of USD 38.55 billion in 2003 increasing to USD 151.182 billion in 2012 . The scale was increased by the trade surplus by nearly four times in 10 years. This value accounts for an absolute proportion in China's total cultural creative industry export trade.

China's cultural service trade is not large in scale but fast in development compared with that of the leading position of export trade of cultural creative products in the world. The export trade volume increased from USD 0.52 billion in 2002 to USD 4.81 billion in 2012. It increased by nearly 10 times in 10 years. Trade surplus has been observed in China's cultural products export in recent years. The export volume of the cultural creative products decreased in 2009 because of the financial crisis but stably increased in the remaining years. A small surplus always exists in the cultural creative service trade compared with the export of cultural creative products. The growth rate from the total cultural service trade ismore rapid than that of the total cultural product trade. This paper uses related data from the United Nations Conference on Trade and Development (UNCTAD) database to compare the present situations of the cultural creative industries

Table 1. China's cultural creative industry trade unit: billion USD.

\begin{tabular}{lcccc}
\hline Years & Export volume & Import volume & Total trade & Trade balance \\
\hline 2003 & 39.070 & 3.672 & 42.742 & 35.398 \\
2004 & 46.503 & 4.365 & 50.867 & 42.137 \\
2005 & 56.720 & 4.673 & 61.393 & 52.047 \\
2006 & 64.297 & 5.265 & 69.562 & 59.032 \\
2007 & 75.228 & 7.112 & 82.34 & 68.116 \\
2008 & 87.428 & 8.278 & 95.705 & 79.149 \\
2009 & 78.50 & 8.291 & 86.441 & 69.859 \\
2010 & 100.762 & 10.002 & 110.764 & 90.76 \\
2011 & 129.787 & 12.758 & 142.545 & 117.029 \\
2012 & 155.995 & 14.703 & 170.695 & 141.289 \\
\hline
\end{tabular}


between China and the world. The UNCTAD divides cultural creative products into arts, audio-visual products, design products, art performance, new media, publications, and visual arts. Copyright trade is not included in cultural creative services. Its statistical data only include advertising market research service, construction and technical services, cultural and recreational services, and research and development services. However, copyright trade export volume in China has been far less than the long-time import volume. Therefore, China's cultural product trade scale is significantly larger than its cultural service trade. Trade deficit is large in the cultural creative service trade.

China has become the world's second largest economy surpassing the European Union and Japan. Thus, Beijing, as a city with a large-scale cultural creative industry export trade in China, has shown the role of China's economic development and industrial transformation.

This paper summarizes the import and export data of Beijing's cultural creative core products and services from 2006 to 2013 based on the classification criteria of Beijing's cultural creative industries. As presented in Figure 2, Beijing's cultural creative industry export trade has shown a substantial increase in export growth rate since 2009 after the sharp slowdown in global trade growth because of the financial crisis. Beijing's cultural creative industry shows good applicability against international trade risk.

Moreover, the cultural creative industry is an emerging strategic industry that is performing well under the 12th Five-Year Plan in the process of developing foreign cultural service trade in Beijing. The export volume of Beijing's cultural creative trade from 2006 to 2013 was more than USD 0.6 billion. Trade export volume was down in 2009 but recovered from 2010 to 2013 with an increasing absolute value of export growth. The cultural creative industry trade volume was USD1.741 billion, which was beyond the overall level before the global financial crisis, until 2013. The total amount of export volume was stable before and after the financial crisis in 2008 to 2009 as Beijing's cultural creative industry continued

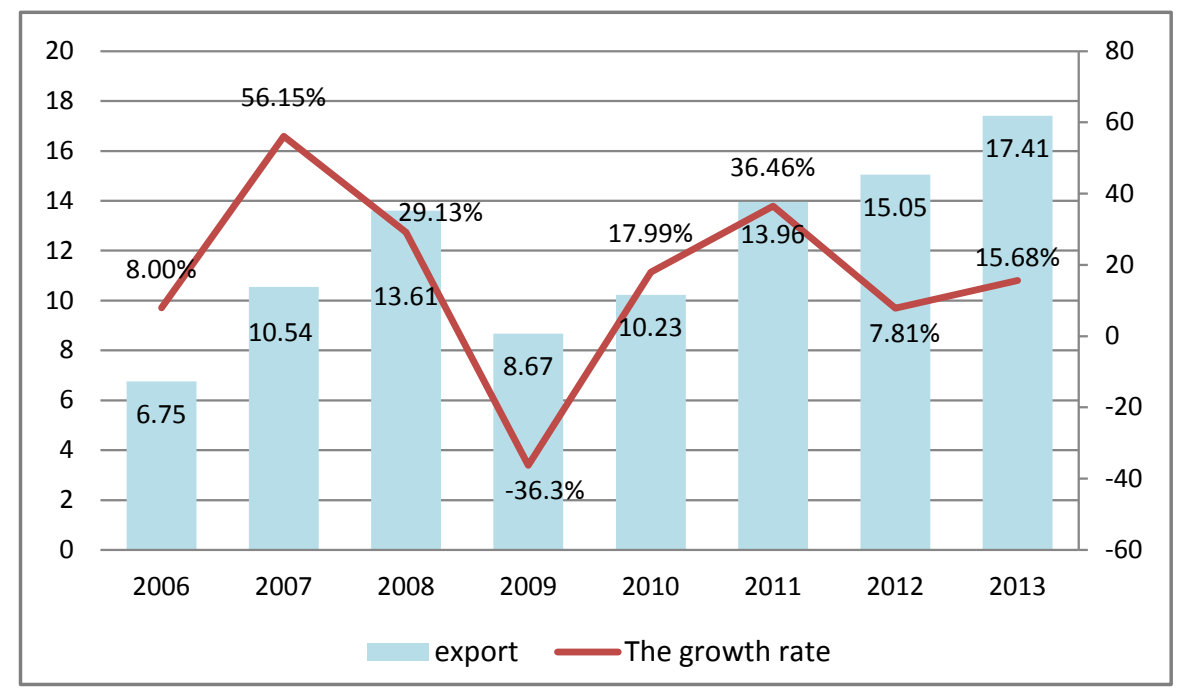

Figure 2. Situation of Beijing's cultural creative industry export trade unit: billion USD. 
to "be out there". Moreover, it highlighted the strong vitality and prospects of Beijing's cultural creative industry export trade.

The situation of Beijing's cultural creative industry import and export trade in 2006 to 2013 (Figure 3) presents a trade surplus from 2006 to 2008. Beijing's cultural creative import and export trade had a slight trade deficit from 2008 to 2013. China has gradually optimized the industrial structure and expanded the scale of cultural trade, but trade deficit in the cultural creative industry still exists. Beijing is the cultural and creative center of China and has a low proportion in the total trade of cultural creative industry export and low international competitiveness. Therefore, Beijing has accelerated the construction of its cultural trade base, integrated its national and international market resources, and developed its creative mechanism to be at the main position, thus promoting China's cultural creative products and services to "be out there".

\subsection{Continuous Optimization of Structure}

Cultural creative industry trade is divided into two parts: tangible and intangible cultural and creative products trade.

In China's cultural products and service export trade, the cultural creative products' export volume usually accounts for more than $95 \%$ and the service export volume accounts for only about $3 \%$ of the cultural creative industry export volume, as shown in Table 2. The comparison of China's cultural products and service export structure with the global cultural products and service export structure indicates that the global cultural creative service export accounts for about $60 \%$, as shown in Table 3 . Therefore, China's cultural creative industry has quickly developed on a larger scale, but it depends on the cultural creative products withwith low added value. The cultural creative industry services contribute less to the trade surplus of China's cultural and creative industries.

Cultural services have higher economic value added than cultural products be-

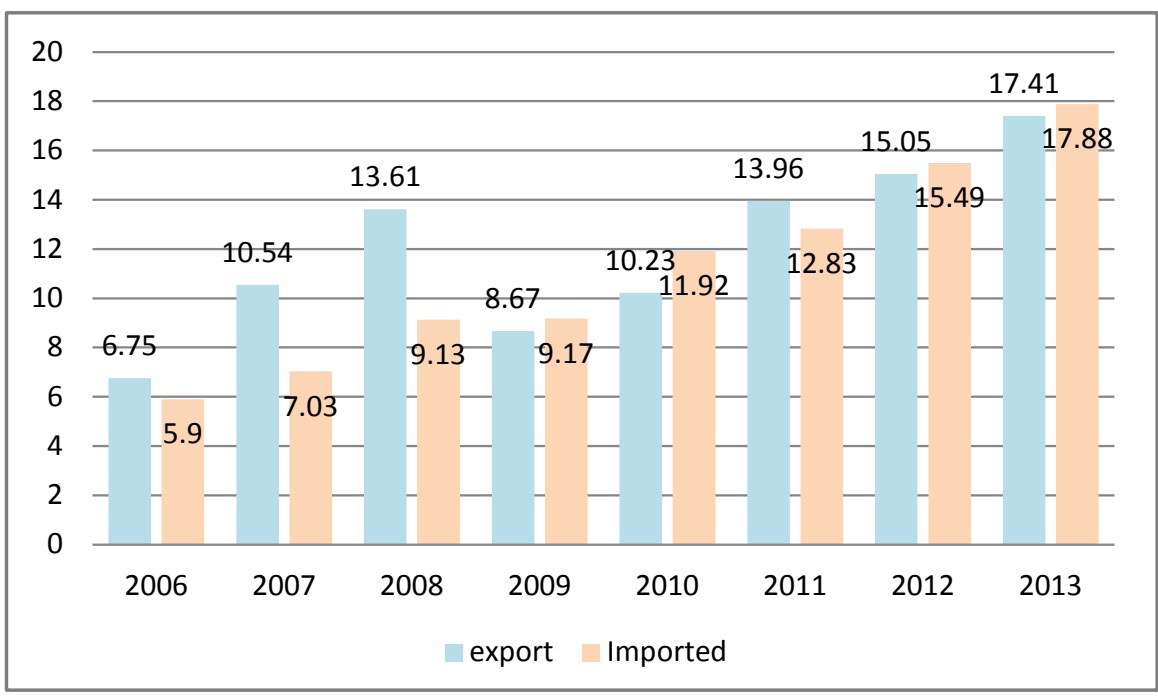

Figure 3. Situation of Beijing's cultural creative industry import and export trade unit: billion USD. 
Table 2. China's cultural creative products and service export structure unit: billion USD.

\begin{tabular}{|c|c|c|c|}
\hline Years & Cultural creative products & Cultural reactive services & Proportion of cultural creative services \\
\hline 2003 & 38.550 & 0.520 & $1.35 \%$ \\
\hline 2004 & 45.612 & 0.891 & $1.95 \%$ \\
\hline 2005 & 55.510 & 1.210 & $2.18 \%$ \\
\hline 2006 & 62.715 & 1.582 & $2.52 \%$ \\
\hline 2007 & 72.999 & 2.229 & $3.05 \%$ \\
\hline 2008 & 84.807 & 2.621 & $3.09 \%$ \\
\hline 2009 & 75.740 & 2.410 & $3.18 \%$ \\
\hline 2010 & 97.754 & 3.008 & $3.08 \%$ \\
\hline 2011 & 125.646 & 4.141 & $3.30 \%$ \\
\hline 2012 & 151.182 & 4.813 & $3.18 \%$ \\
\hline
\end{tabular}

Data source: UNCTAD database.

Table 3. Global cultural creative products and service export structure unit: billion USD.

\begin{tabular}{|c|c|c|c|}
\hline Years & Cultural creative products & Cultural reactive services & Proportion of cultural creative services \\
\hline 2003 & 223.795 & 112.231 & $50.15 \%$ \\
\hline 2004 & 259.047 & 142.963 & $55.19 \%$ \\
\hline 2005 & 287.517 & 163.647 & $56.92 \%$ \\
\hline 2006 & 313.108 & 183.357 & $58.56 \%$ \\
\hline 2007 & 364.423 & 222.749 & $61.12 \%$ \\
\hline 2008 & 417.285 & 256.883 & $61.56 \%$ \\
\hline 2009 & 375.306 & 243.017 & $64.75 \%$ \\
\hline 2010 & 416.323 & 253.462 & $60.88 \%$ \\
\hline 2011 & 489.814 & 287.018 & $58.60 \%$ \\
\hline 2012 & 473.791 & 293.828 & $62.02 \%$ \\
\hline
\end{tabular}

Data source: UNCTAD database.

cause they transfer more cultural information outside. Thus, although China is performing well in the cultural creative products trade and is considered a huge country, the present situation of its cultural creative industry export structure is not ideal and needs much improvement.

Beijing's cultural creative industry international trade has expanded in size in the past 10 years. However, its industrial structure shows different developing trends from China's cultural creative industrial structure. This paper collects related data on the export of service trade in Beijing from 2006 to 2012. The result shows that Beijing's core cultural service trade of cultural creative industry has trade surplus. Further study shows that advertisement has trade surplus, whereas audio and video, copyright royalties, and other service trades generally have trade deficit.

The export trade of core cultural creative services that focuses on advertisements, audio and video, and copyright royalties is dominant and accounts for nearly one-third of the whole country's enterprises at the current stage of Beijing's 
foreign trade of cultural creative industries. The export trade of cultural creative products is in sharp contrast to that of cultural creative services and accounts for less than $1 \%$ of the export volume of the same product exports in the country. Moreover, statistical data show that Beijing's foreign trade of core cultural creative products has trade deficit. However, Beijing's foreign trade of core cultural creative services has been noted to have trade surplus in recent years (Figure 4 and Figure 5).

The data in the past few years show that China regards cultural creative products as the main export category. However, Beijing is more dominant in the core cultural creative service export. For example, Beijing's cultural creative service trade had trade surplus in 2012, and its export volume accounted for $28.03 \%$ of the same services in China. Thus, Beijing pays more attention to the adjustment of industrial structure and focuses on the development of cultural and creative

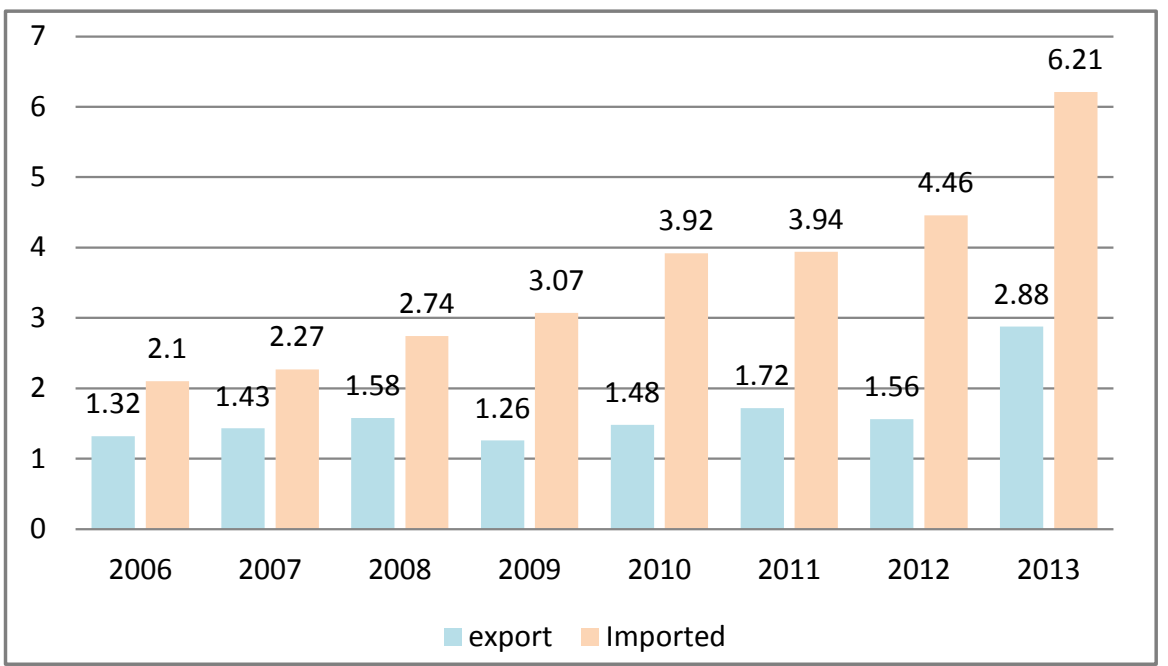

Figure 4. Import and export trade of Beijing's core cultural products unit: billion USD. Data source: Report on the development of trade in services in Beijing.

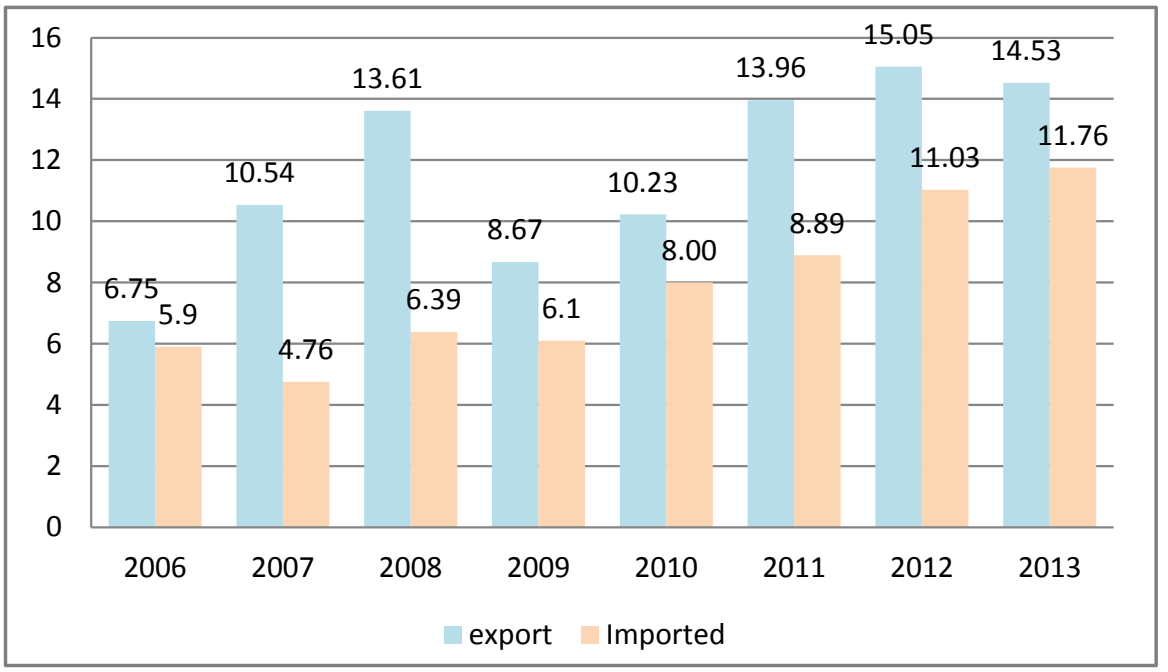

Figure 5. Import and export trade of Beijing's core cultural services unit: billion USD. Data source: Report on the development of trade in services in Beijing. 
industries and service trade, as shown in Table 4 and Table 5.

The core cultural services are classified to further analyze Beijing's cultural creative industrial structure. Advertisement export in Table 6 showed a rising trend, although it was down for a short period in 2009. It increased from USD 0.431 billion in 2009 to USD 1.263 billion in 2012, and it always had trade surplus. Audio and video export broke through USD 0.2 billion in 2007 and 2008 and

Table 4. Export trade of Beijing's cultural creative products and services unit: billion USD.

\begin{tabular}{ccccccc}
\hline Years & $\begin{array}{c}\text { Beijing's cultural creative } \\
\text { products }\end{array}$ & $\begin{array}{c}\text { National cultural creative } \\
\text { products }\end{array}$ & $\begin{array}{c}\text { Beijing's } \\
\text { proportion }\end{array}$ & $\begin{array}{c}\text { Beijing's cultural creative } \\
\text { services }\end{array}$ & $\begin{array}{c}\text { National cultural creative } \\
\text { services }\end{array}$ & $\begin{array}{c}\text { Beijing's } \\
\text { proportion }\end{array}$ \\
\hline 2006 & 0.132 & 62.715 & $0.21 \%$ & 0.543 & 1.582 & $34.32 \%$ \\
2007 & 0.143 & 72.999 & $0.20 \%$ & 0.911 & 2.229 & $40.87 \%$ \\
2008 & 0.158 & 84.807 & $0.19 \%$ & 1.203 & 2.621 & $45.90 \%$ \\
2009 & 0.126 & 75.740 & $0.17 \%$ & 0.741 & 2.410 & $30.75 \%$ \\
2010 & 0.148 & 97.754 & $0.15 \%$ & 0.875 & 3.008 & $29.09 \%$ \\
2011 & 0.172 & 125.646 & $0.14 \%$ & 1.224 & 4.141 & $29.56 \%$ \\
2012 & 0.156 & 151.182 & $0.10 \%$ & 1.349 & 4.813 & $28.03 \%$ \\
\hline
\end{tabular}

Data source: Report on the development of trade in services in Beijing; Beijing Customs Statistics Yearbook.

Table 5. Import trade of Beijing's cultural creative products and services unit: billion USD.

\begin{tabular}{ccccccc}
\hline Years & $\begin{array}{c}\text { Beijing's cultural creative } \\
\text { products }\end{array}$ & $\begin{array}{c}\text { National cultural creative } \\
\text { products }\end{array}$ & $\begin{array}{c}\text { Beijing's } \\
\text { proportion }\end{array}$ & $\begin{array}{c}\text { Beijing's cultural creative } \\
\text { services }\end{array}$ & $\begin{array}{c}\text { National cultural creative } \\
\text { services }\end{array}$ & $\begin{array}{c}\text { Beijing's } \\
\text { proportion }\end{array}$ \\
\hline 2006 & 0.210 & 4.185 & $5.02 \%$ & 0.380 & 1.080 & $35.19 \%$ \\
2007 & 0.227 & 5.622 & $4.04 \%$ & 0.476 & 1.490 & $31.95 \%$ \\
2008 & 0.274 & 6.078 & $4.51 \%$ & 0.639 & 2.200 & $29.05 \%$ \\
2009 & 0.307 & 6.061 & $5.07 \%$ & 0.610 & 2.230 & $27.35 \%$ \\
2010 & 0.392 & 7.592 & $5.16 \%$ & 0.800 & 2.410 & $33.20 \%$ \\
2011 & 0.394 & 9.578 & $4.11 \%$ & 0.889 & 3.180 & $27.96 \%$ \\
2012 & 0.446 & 11.373 & $3.92 \%$ & 1.103 & 3.330 & $33.12 \%$ \\
\hline
\end{tabular}

Data source: Report on the development of trade in services in Beijing; Beijing Customs Statistics Yearbook.

Table 6. Import trade of Beijing's subdivided cultural creative services units: billion USD.

\begin{tabular}{ccccccc}
\hline \multirow{2}{*}{ Years } & \multicolumn{2}{c}{ Advertisements } & \multicolumn{2}{c}{ Movies and audio-video } & \multicolumn{2}{c}{ Copyright royalties } \\
\cline { 2 - 7 } & Export & Import & Export & Import & Export & Import \\
\hline 2006 & 0.431 & 0.247 & 0.087 & 0.072 & 0.025 & 0.061 \\
2007 & 0.629 & 0.341 & 0.264 & 0.116 & 0.018 & 0.019 \\
2008 & 0.812 & 0.447 & 0.369 & 0.168 & 0.022 & 0.024 \\
2009 & 0.651 & 0.394 & 0.067 & 0.187 & 0.023 & 0.029 \\
2010 & 0.763 & 0.491 & 0.081 & 0.273 & 0.031 & 0.036 \\
2011 & 1.157 & 0.620 & 0.067 & 0.269 & 0.026 & 0.177 \\
2012 & 1.263 & 0.651 & 0.072 & 0.415 & 0.014 & 0.037 \\
2013 & 1.332 & 0.684 & 0.096 & 0.437 & 0.025 & 0.046 \\
\hline
\end{tabular}


then decreased to USD 0.1 billion in the rest of the year without an obvious rising trend. The import volume of audio and video was always in a rising trend. For example, the import and export volume of movies and audio and video service was USD 0.491 billion in 2012, up by $46.22 \%$ in the same period in the previous year. Export volume was USD 0.072 billion, which was only up by $7 \%$ in the same period of the previous year. The import and export trade of copyright royalties remained almost unchanged from 2006 to 2012 and showed a significantly negative growth from 2011 to 2012 . The three categories of cultural creative service subdivisions indicate that the current situation of Beijing's advertisement service trade is good, but movies, TV, audio and video service, and copyright royalties that truly reflect the cultural value of the Chinese nation still need improvement.

\subsection{Flow Direction of Export Trade}

\subsubsection{Flow Direction of Cultural Creative Product Export Trade}

Export volume has increased gradually in recent years with the increasing development of Beijing's foreign trade in cultural creative industry. However, the major trading partners focus on developed countries, and the core cultural products have move on to the United States, Japan, Britain, Germany, Australia, Southeast Asia, and Canada, which account for $67 \%$ of the total export volume, as shown in Figure 6.

\subsubsection{Flow Direction of Cultural Creative Service Export Trade}

The trading partners in advertisement and publication service of Beijing are mainly the United States, Hong Kong, Germany, Britain, and Korea, with a total proportionof more than $70 \%$. For example, 126 trading partners were involved in advertisement and publication services in Beijing in 2013. The top five trading partners of Beijing were the United States, Hong Kong, Singapore, Korea, and Germany, which accounted for $24.24 \%, 22.44 \%, 11.62 \%, 7.66 \%$, and $7.36 \%$ of the

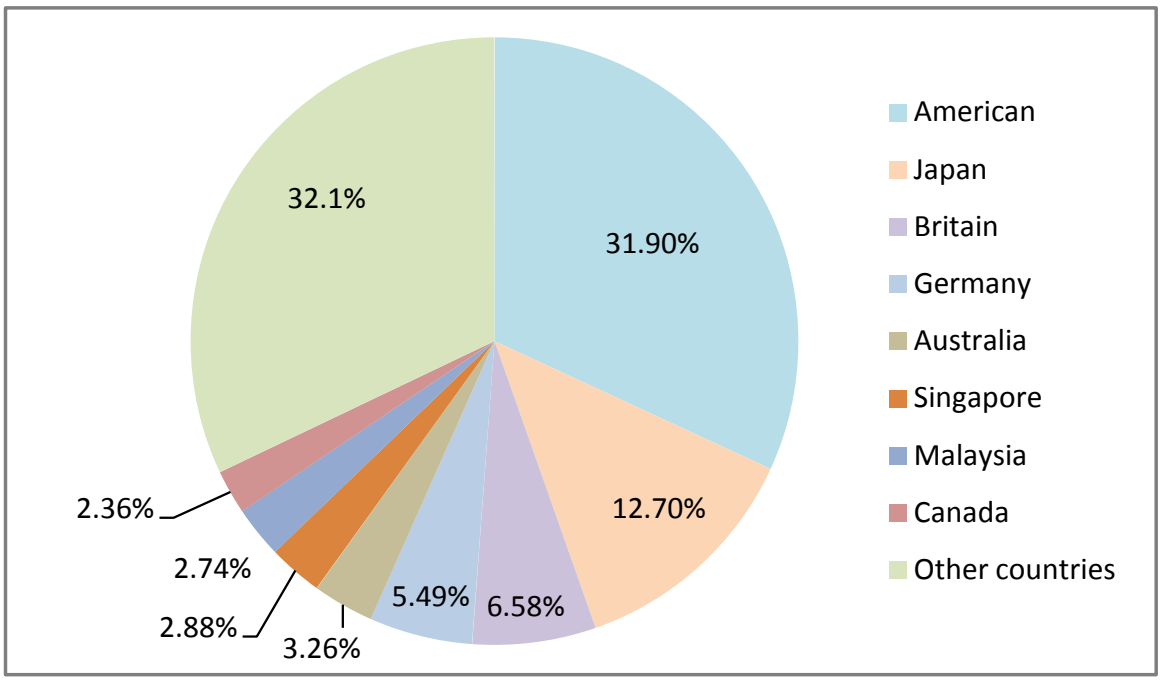

Figure 6. Export trading partners of Beijing's cultural creative products. Data source: Report on the development of trade in services in Beijing; Beijing customs statistics yearbook. 
total trading partners, respectively. About 89 trading partners were involved in the movies and audio-video industry in Beijing. Its largest trading partner was the United States, which accounted for $38.45 \%$, followed by Hong Kong, Japan, the United Kingdom, and Canada. Its trading partners in copyrights were Southeast Asia, Hong Kong, the United States, and Canada, and its export trading partners in the cultural creative services were the United States, Hong Kong, Taiwan, Korea, and Southeast Asia, thus accounting for 65\%, as shown in the Figure 7.

\section{Competitiveness of Beijing's Cultural Creative Industries}

The statistics issued by the Department of Trade shows that cultural trade has two parts: core cultural product import and export and core cultural service import and export. This paper aims to explain the main characteristics of Beijing's cultural creative industry export. The competitiveness of cultural creative industries refers to the export capacity of a particular industry in a country or a region in international competition under the liberalization of international trade. Moreover, it is a direct reflection of the comparative advantages of the competitiveness of a particular industry in this country or region.

International competitiveness shows the relative advantages of products in the international market. Products with stronger international competitiveness easily attract the favor of trading partners. Beijing's core cultural products mainly cover cultural heritage, printed products, audio-visual products, visual arts, audio-visual media, and others (i.e., Xuan paper, writing brush, and musical instruments). The following section analyzes and evaluates the international competitiveness of Beijing's cultural creative products and the classified products from the international market share (MS), Index of Revealed Comparative Advantage (RCA), and trade competitiveness index (TC).

\subsection{Overall Level}

\subsubsection{International Market Share (MS)}

MS refers to the proportion of the total export of product or service in a country

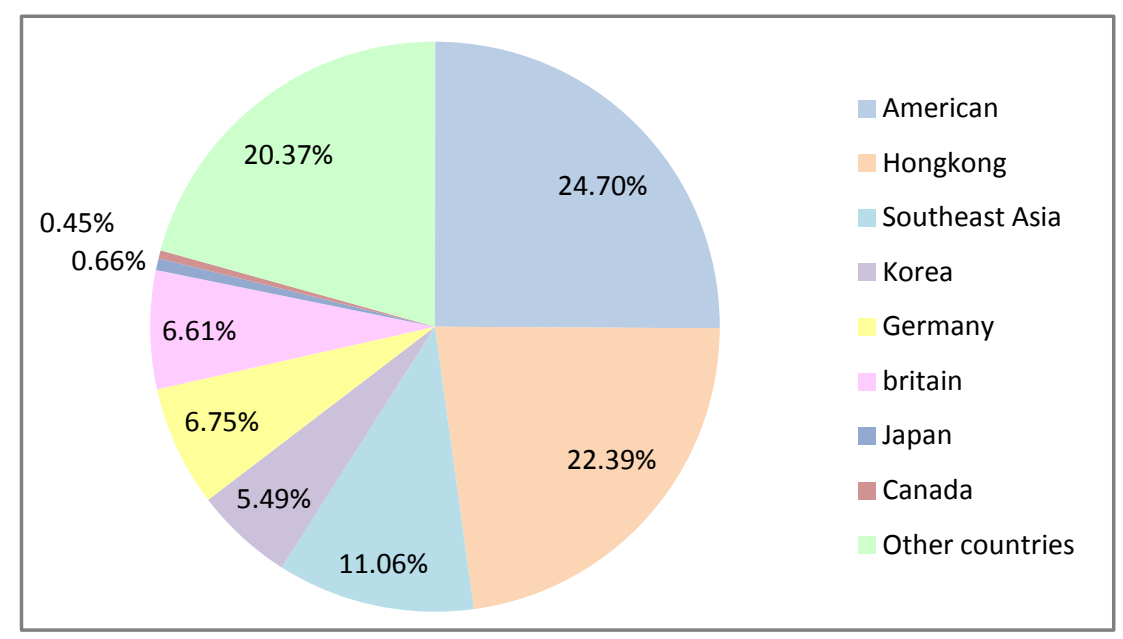

Figure 7. Beijing's trading partners in the cultural creative services. Data source: Report on the development of trade in services in Beijing; Beijing customs statistics yearbook. 
or a region to the total export of the same product or service in the world. It reflects the intensity of international competitiveness of the product or service in the country. When MS is high, the international competitiveness of this product or service in this country or region is strong. Therefore, $\mathrm{MSi}=\mathrm{Xi} / \mathrm{X}$, where MSi is the MS of the cultural creative product or service in a certain country or a certain region, $\mathrm{Xi}$ is the export volume of the cultural creative product or service in the country or region, and $\mathrm{X}$ is the total export volume of the global cultural creative products or services.

1) Cultural creative products

Table 7 shows that the MS of Beijing's cultural creative products is always low with a significant gap from the international position of China's cultural creative products. However, Beijing has paid increasing attention to the development of cultural creative industries in recent years. The cultural creative industries have become a new growth point because of its huge potential. Given its complete policies, a comprehensive security platform was constructed to provide strong support for the key cultural creative enterprises to form a highly influential industrial cluster. The radiation driving effects of these clustering areas can contribute more to the promotion of the international competitiveness of Beijing's cultural creative products.

2) Cultural creative services

Beijing's cultural creative service export increased by $20 \%$ annually from 2006 to 2012 similar to the growth rate of the same type of service export in China with MS of $0.3 \%$, as shown in Table 8. It had a declining trend in 2009 after the financial crisis. The market share in 2012 was slightly higher than that in 2006. The United States had the highest MS among Beijing's trading partners in the cultural creative services, and it was followed by the United Kingdom. China had a similar market share to Japan, but the increasing range was higher in China.

\subsubsection{Index of Revealed Comparative Advantage (RCA)}

RCA is commonly used to reflect the international competitiveness of a certain industry with a higher value of economic analysis. It reflects the competitiveness of a certain product in a country or a region in the international market. RCA is the proportion of export volume of a certain product in a country or a region to

Table 7. Market share of Beijing's cultural creative products unit: \%.

\begin{tabular}{cccccc}
\hline Years & Beijing & China & Japan & The United states & The United Kingdom \\
\hline 2006 & 0.042 & 20.03 & 1.59 & 8.48 & 5.86 \\
2007 & 0.039 & 20.05 & 1.76 & 8.74 & 5.9 \\
2008 & 0.038 & 20.32 & 1.67 & 8.65 & 4.97 \\
2009 & 0.034 & 20.18 & 1.39 & 8.77 & 4.52 \\
2010 & 0.036 & 23.48 & 1.40 & 8.41 & 4.86 \\
2011 & 0.035 & 25.65 & 1.28 & 8.53 & 4.98 \\
2012 & 0.033 & 31.91 & 1.45 & 8.69 & 5.01 \\
\hline
\end{tabular}


the global export volume of the same product. It can better reflect the relative superiority in the export of a certain product in a country or a region in the world, excluding the influencing factors of the fluctuation in national and global total volume [3].

RCA can be represented by the following formula: $\mathrm{RCA}_{i j}=\frac{X_{i j} / X_{t j}}{X_{i w} / X_{t w}}$, where $X_{i j}$ is the export volume of product $i$ in $j$ region, $X_{t j}$ is the total export volume in $j$ region, $X_{i w}$ is the export volume of product $i$ in the world, and $X_{t w}$ is the total export volume of services and products in the world. Strong international competitiveness is observed when RCA $\geq 2.5$, strong international competitiveness is noted when $1.25 \leq \mathrm{RCA}<2.5$, and weak international competitiveness is indicated when RCA $<0.8$ [4].

This paper reports the export volume of cultural creative industries in Beijing, China, the United States, and Japan; the global cultural creative industry; and the total export of Beijing, China, the United States, Japan, and the world from 2006 to 2012. The data obtained from the RCA formula are shown in Table 9. The analysis shows that Beijing's RCA indexes did not reach 0.8 from 2006 to 2012. The criteria of RCA index indicate that the international competitiveness of Beijing's cultural creative industries is weak, but a growth trend is observed compared with the situation in 2006. Thus, the international competitiveness of this industry in Beijing has gradually increased. Moreover, the data show that China's RCA is greater than 2.5. Thus, China has strong international competitiveness. The international competitiveness of the cultural creative industries in the United States and Japan is less than that of China. Beijing's RCA is higher than that of Japan

Table 8. Market share of Beijing's cultural creative services unit: \%.

\begin{tabular}{cccccc}
\hline Years & Beijing & China & Japan & The United States & The United Kingdom \\
\hline 2006 & 0.296 & 0.863 & 0.97 & 12.75 & 5.27 \\
2007 & 0.409 & 1.001 & 0.99 & 12.82 & 5.32 \\
2008 & 0.468 & 1.020 & 1.01 & 12.91 & 4.53 \\
2009 & 0.305 & 0.992 & 1.03 & 12.58 & 4.32 \\
2010 & 0.345 & 1.187 & 1.20 & 12.47 & 4.34 \\
2011 & 0.426 & 1.443 & 1.24 & 12.52 & 4.56 \\
2012 & 0.459 & 1.638 & 1.25 & 12.69 & 4.68 \\
\hline
\end{tabular}

Table 9. RCA of cultural creative industries in Beijing, China, and other countries.

\begin{tabular}{ccccc}
\hline Years & Beijing & China & The United States & Japan \\
\hline 2006 & 0.367 & 2.738 & 0.897 & 0.341 \\
2007 & 0.510 & 2.568 & 0.917 & 0.675 \\
2008 & 0.567 & 2.643 & 0.931 & 0.613 \\
2009 & 0.365 & 2.594 & 0.896 & 0.537 \\
2010 & 0.526 & 2.784 & 0.884 & 0.474 \\
2011 & 0.688 & 2.816 & 0.923 & 0.482 \\
2012 & 0.746 & 2.887 & 0.958 & 0.408 \\
\hline
\end{tabular}


but does not reach China's competitiveness.

Further analysis on the revealed comparative advantage of Beijing's cultural creative industry products and services (Table 10) shows no obvious change in the RCA of Beijing's cultural creative products from 2006 to 2007 and maintains a low level. The RCA of Beijing's cultural creative services gradually increases. Therefore, the international competitiveness of Beijing's cultural creative industries mainly relies on the development of cultural creative services.

\subsection{Industry Level}

TC is commonly used to analyze the trade competitiveness of a product or service in a country or a region in the internal structure.

TC is a flow index for analyzing international competitiveness. It is a ratio of the net export volume of a certain industry or a product in a country to its total imports and exports. TC represents the proportion of the balance of foreign trade in a country to total imports and exports. In this paper, TCi refers to the TC of cultural creative products or services in a certain country or a region, $\mathrm{Xi}$ is the export volume of cultural creative products or services in the country or region, and $\mathrm{Mb}$ is the import volume. The formula is as follows: $\mathrm{TCi}=(\mathrm{Xi}-\mathrm{Mi}) /(\mathrm{Xi}+\mathrm{Mi})[5]$.

The range of this index is $[-1,1]$. TCb that is greater than 0 indicates that trade surplus exists in the cultural creative products in this country or region and that the products have strong trade competitiveness. If $\mathrm{TCb}$ is closer to 0 , competitiveness becomes weaker. If $\mathrm{TCb}$ is less than 0 , trade deficit exists in the cultural creative products in this country or region, and the products do not have strong trade competitiveness. TC in the level of cultural creative industries is usually divided into the following six situations, as shown in Table 11 [6].

\subsubsection{Cultural Creative Products}

Table 12 shows a severe trade deficit in Beijing's cultural creative products. Unlike China's trade competitiveness in recent years, Beijing's cultural creative products clearly do not have a competitive advantage. Trade deficit remains in the cultural creative products in developed countries. Beijing's cultural creative products are mainly divided into six categories. Therefore, this paper aims to analyze their competitiveness in six industries.

The meaning of the TC range in Table 13 shows that Beijing has strong com-

Table 10. RCA of Beijing's cultural creative products and services.

\begin{tabular}{lcc}
\hline Years & Beijing's cultural creative products & Beijing's cultural creative services \\
\hline 2006 & 0.072 & 0.295 \\
2007 & 0.069 & 0.441 \\
2008 & 0.066 & 0.501 \\
2009 & 0.053 & 0.312 \\
2010 & 0.076 & 0.450 \\
2011 & 0.085 & 0.603 \\
2012 & 0.077 & 0.669 \\
\hline
\end{tabular}


parative advantages in Xuan paper, writing brush, musical instruments, and other industries and weak comparative advantages in the visual arts industry. Moreover, Beijing has strong comparative disadvantages in cultural heritage, printed products, audio-visual products, and audio-visual media industries. China's competitive advantages in the cultural creative products mainly focus on cultural heritage, visual arts, Xuan paper, writing brush, musical instruments, and some traditional industries. The products are mainly labor-intensive and resource-intensive. Beijing's competitiveness in various industries does not reach China's competitivenesslevel. However, its competitive advantages in visual arts, Xuan paper, writing brush, musical instruments, and other industries are higher than those in Japan, the United States, and the United Kingdom.

\subsubsection{Cultural Creative Services}

Table 14 shows that the competitiveness indexes of the core cultural creative

Table 11. Meanings of TC range.

\begin{tabular}{cc}
\hline Index range & Meanings \\
\hline $0.8 \leq \mathrm{TC}<1$ & Very strong comparative advantage \\
$0.5 \leq \mathrm{TC}<0.8$ & Stronger comparative advantage \\
$0 \leq \mathrm{TC}<0.5$ & Weak comparative advantage \\
$-0.5 \leq \mathrm{TC}<0$ & Weak comparative disadvantage \\
$-0.8 \leq \mathrm{TC}<-0.5$ & Stronger comparative disadvantage \\
$1 \leq \mathrm{TC}<-0.8$ & Very strong comparative advantage \\
\hline
\end{tabular}

Table 12. TC of cultural creative products.

\begin{tabular}{ccccc}
\hline Years & Beijing & China & The United States & Developed countries \\
\hline 2006 & -0.228 & 0.849 & 0.097 & -0.188 \\
2007 & -0.227 & 0.827 & 0.031 & -0.185 \\
2008 & -0.269 & 0.827 & 0.015 & -0.165 \\
2009 & -0.418 & 0.808 & 0.130 & -0.176 \\
2010 & -0.452 & 0.819 & 0.052 & -0.185 \\
2011 & -0.392 & 0.821 & 0.067 & -0.173 \\
2012 & -0.482 & 0.828 & 0.078 & -0.186 \\
\hline
\end{tabular}

Table 13. TC of various industries of the cultural creative industry.

\begin{tabular}{cccccc}
\hline Cultural creative products & Beijing & China & Japan & The United States The United Kingdom \\
\hline Cultural heritage & -0.537 & 0.829 & -0.422 & -0.636 & -0.614 \\
Printed products & -0.735 & 0.431 & 0.055 & 0.012 & 0.171 \\
Audio-video products & -0.683 & 0.423 & -0.316 & -0.142 & -0.283 \\
Visual arts & 0.221 & 0.962 & -0.074 & -0.079 & 0.087 \\
Visual media & -0.637 & -0.969 & -0.901 & 0.811 & 0.352 \\
$\begin{array}{c}\text { Others (i.e., Xuan paper, writing } \\
\text { brush, and musical instruments) }\end{array}$ & 0.575 & 0.764 & -0.126 & -0.439 & -0.317 \\
\hline
\end{tabular}


services are greater than 0 , which indicates that they have a certain trade competitive advantage. Further analysis on the categories of cultural creative services (i.e., advertisements, movie and audio-video industry, and copyright royalties) shows that trade surplus is found in advertisements, and trade deficit is found in movie and audio-video industry and copyright royalties.

The meaning of the TC index range divides the comparative advantages of Beijing's cultural creative industries, as shown in Table 15. Beijing has weak comparative advantages in advertisements and publicity in 2006 to 2012 and weak comparative advantages in movie and audio-video industry in 2006 to 2008. It has weak comparative disadvantages in 2009 and stronger comparative disadvantages in 2010 to 2012. Thus, the international competitiveness of movie and audio-video industry has gradually decreased in recent years. Copyright royalties have weak comparative disadvantages without significant change.

\section{Comprehensive Evaluation of the Competitiveness of Beijing's Cultural Creative Industries}

This paper conducts a comprehensive analysis and evaluation of the overall international competitiveness of Beijing's cultural creative industries by studying the MS, RCA, and TC of Beijing's cultural creative industries.

Table 14. TC of various industries of the cultural creative industry.

\begin{tabular}{lcccc}
\hline \multicolumn{4}{l}{ Years Cultural creative services Advertisements Movie and audio-video industry Copyright royalties } \\
\hline 2006 & 0.177 & 0.271 & 0.094 & -0.419 \\
2007 & 0.314 & 0.297 & 0.389 & -0.027 \\
2008 & 0.306 & 0.290 & 0.374 & -0.043 \\
2009 & 0.097 & 0.246 & -0.472 & -0.115 \\
2010 & 0.045 & 0.217 & -0.542 & -0.075 \\
2011 & 0.159 & 0.302 & -0.601 & -0.744 \\
2012 & 0.100 & 0.320 & -0.704 & -0.451 \\
\hline
\end{tabular}

Table 15. Competitiveness advantages of Beijing's cultural creative service industries.

\begin{tabular}{|c|c|c|c|c|c|c|}
\hline \multirow{2}{*}{ Years- } & \multicolumn{3}{|c|}{ Comparative advantages } & \multicolumn{3}{|c|}{ Comparative disadvantages } \\
\hline & Very strong & Strong & Weak & Weak & Strong & Very strong \\
\hline 2007 & - & - & $\begin{array}{l}\text { Advertisements and publicity, } \\
\text { movie and audio-video }\end{array}$ & Copyright royalties & -- & -- \\
\hline 2008 & -- & - & $\begin{array}{l}\text { Advertisements and publicity, } \\
\text { movie and audio-video }\end{array}$ & Copyright royalties & -- & -- \\
\hline 2009 & - - & -1 & Advertisements and publicity & Movie, audio-video, and copyright royalties & - - & - - \\
\hline 2010 & - & -- & Advertisements and publicity & Copyright royalties & Movie and audio-video & - \\
\hline 2011 & - - & -- & Advertisements and publicity & Copyright royalties & Movie and audio-video & - - \\
\hline
\end{tabular}


First, Beijing's cultural creative industry has a low market share, and its cultural creative services have a higher MS than its cultural creative products. This finding shows a small difference from the same services in China.

Second, the exports of Beijing's cultural creative industries have weaker comparative advantages. These exports exclude the influencing factors of the fluctuation in national and global total volume. However, competitiveness shows a rising trend. Beijing is stronger than Japan in comparative advantages and is catching up with the United States. The comparison of RCA and TC shows that the conclusions from these two indexes are strongly consistent. Therefore, a significant correspondence is found between the comparative advantages of cultural creative industries and trade competitiveness in Beijing.

Finally, the analysis of the TC of cultural creative subdivisions shows that the average value of TC in the cultural creative products in recent years is -0.353 , which indicates that the cultural creative products have competitive disadvantage, and the disadvantages are more severe. Only visual arts, Xuan paper, writing brush, musical instruments, and other subdivisions are competitive, but they are weak. The TC of cultural creative service is higher than that of cultural creative products, but the overall competitiveness is not stable. The analysis of the TCs of the three major industries presents that the improvement of the competitiveness of Beijing's movie and audio-video industries in 2007 and 2008 drives the overall competitiveness of Beijing's cultural creative service trade. However, the competitiveness of the movie industry remains in a declining trend in 2009 to 2012. Advertisements and publicity have a rising trend but have weak competitiveness. The copyright industry has significantly competitive disadvantages but has an unstable fluctuation.

\section{Funding}

This work is supported by the Project of Construction of Innovative Teams and Selection and Development of Excellent Talents for Beijing Institute of Fashion Technology (Project Number: PTTBIFT_XZ_006).

\section{References}

[1] Li, Y. (2015) The Proportion of Beijing's Cultural Creative Industries to GDP Broke through $13 \%$. http://bjrb.bjd.com.cn/html/2015-03/12/content_263296.htm

[2] The Department of Trade (2014) 2013-2014 List of Key Enterprises and Key Projects of National Cultural Export. http://fms.mofcom.gov.cn/article/jingjidongtai/201405/20140500596621.shtml

[3] Fu, C.Y. and Chen, Y. (2006) Comparative Advantage of China's Export Commodities: 1980-2000. Economics, No. 1, 579-590.

[4] Zhang, J.C. (2002) Theory and Method of International Competitiveness Evaluation. Economic Science Press, Beijing.

[5] Hou, X. and Li, F. (2011) Analysis of Traffic Index of Service Trade. Business Manager, No. 2, 74-75.

[6] Pei, C.H. and Wang, L. (2002) On the Theoretical Concepts and Analytic Methods of International Competitiveness. China Industrial Economy, No. 4, 41-45. 
Submit or recommend next manuscript to SCIRP and we will provide best service for you:

Accepting pre-submission inquiries through Email, Facebook, LinkedIn, Twitter, etc. A wide selection of journals (inclusive of 9 subjects, more than 200 journals)

Providing 24-hour high-quality service

User-friendly online submission system

Fair and swift peer-review system

Efficient typesetting and proofreading procedure

Display of the result of downloads and visits, as well as the number of cited articles Maximum dissemination of your research work

Submit your manuscript at: http://papersubmission.scirp.org/

Or contact ajibm@scirp.org 